\title{
Market Power in Music Retailing: The Case of Wal-Mart
}

\author{
Mark A. Fox
}

The retailing of pre-recorded music has been an area of investigation that has long been neglected by popular music researchers. This paper focuses on the world's largest music retailer, Wal-Mart, and its impact on traditional chain and independent music retailers. Many of the compact discs sold by Wal-Mart are sold as loss-leaders to attract consumers to buy other products. The response of traditional retailers to Wal-Mart and other massmarket discounters, i.e. minimum advertised price programs, is examined-as is the inability of traditional music retailers to claim that Wal-Mart is engaging in predatory pricing. I then examine the impact of Wal-Mart on the censorship of music. The paper concludes with some directions for future research, including a call for an examination of how traditional retailers can effectively compete against mass-market discounters.

\section{Introduction}

In the United States concerns about the abuse of market power in the music industry tend to focus on the following issues:

- Oligopoly power-the "Big Four" labels (EMI, Sony-BMG, Universal, and Warner) control $80 \%$ of worldwide music sales ("Sony and BMG").

- Ticket sales, where Ticketmaster holds a near monopoly by virtue of exclusive contracts with most major concert venues ("Pearl Jam's Testimony").

- Concert production and promotion-one company, Clear Channel Communications, generates around $70 \%$ of concert revenues in the US through their music production and promotion division (Clear Channel).

- Clear Channel also owns around 1,200 radio stations nationwide, dominates the Top 40 format and controls $60 \%$ of all rock formats (Boehlert, "Suit"; Yang).

- Payola-the Attorney General for New York is currently investigating the use of independent promoters by record companies seeking to have their artists played by radio stations (Boehlert, "Payola"; Hopkins).

- Music television, where Viacom dominates through its ownership of the VH1, MTV, MTV2, and Country Music Television networks. 
- Artist contracts, where artists claim that labels use their power to misrepresent royalties or bind them to contracts (under the so-called "seven-year rule") that would not be permissible in other professions.

While these areas are certainly worthy of our attention, this paper will focus on an oftentimes ignored aspect of market power, namely market power in music retailing. In general, music retailing has been neglected as an area of investigation by popular music scholars. As Paul du Gay and Keith Negus observe, "[t]he record shop has been strangely absent from most histories of pop, and neglected or merely mentioned in passing accounts of its production and consumption" (397).

From an examination of the popular and business press over recent years, one could be forgiven for believing that the major threat facing chain and independent music stores is the advent of digital downloads. For example, in 2000 Eric Boehlert proposed that " $[\mathrm{c}]$ onfronted by an apocalyptic mix of blank CDs and Napster, the record shop faces extinction-in 12 months" ("The Death of Music Retail"). More recently, in 2004, Pimm Fox suggests: "Call it the neutron-bomb effect: In less than a decade, the aisles of music retailers will be empty. I predict that online music sites such as Apple's iTunes, Napster and Sony's Connect will have drained Virgin Megastores, HMVs and Tower Records of their customers."

With the rapid growth of peer-to-peer services and the emergence of pay-per-song and subscription sites, it is hardly surprising that the music industry has paid considerable attention to the competitive impact of music being made available online (for free, through piracy, or commercially). ${ }^{1}$ However, contrary to rumors of their demise, brick-and-mortar retail stores remain the major source of music sales. According to the Recording Industry Association of America (RIAA), these stores accounted for $86 \%$ of music sales in 2003 - see Table 1 . What is most telling about sales of music from brick-and-mortar stores is the increased influence of stores that we would not consider to be traditional record stores. A key contention of this paper is that these non-traditional record stores, typically mass-market discounters-such as Best Buy, Circuit City, Target, K-Mart, and Wal-Mart-have amassed significant

Table 1 Market Share of Music Distribution Channels, 1989 to 2003, Based on Manufacturers' Shipments at Suggested List Prices

\begin{tabular}{lrrrrrrrrrrrrrrrrr}
\hline & 1989 & 1990 & 1991 & 1992 & 1993 & 1994 & 1995 & 1996 & 1997 & 1998 & 1999 & 2000 & 2001 & 2002 & 2003 \\
\hline $\begin{array}{l}\text { Record Store } \\
\text { Other Store }\end{array}$ & 15.7 & 69.8 & 62.1 & 60.0 & 56.2 & 53.3 & 52.0 & 49.9 & 51.8 & 50.8 & 44.5 & 42.4 & 42.5 & 36.8 & 33.2 \\
$\begin{array}{l}\text { Tape/Record } \\
\text { Club }\end{array}$ & 7.9 & 8.9 & 11.1 & 11.4 & 12.9 & 15.1 & 14.3 & 14.3 & 11.6 & 9.0 & 7.9 & 7.6 & 6.1 & 4.0 & 4.1 \\
$\begin{array}{l}\text { TV, Newspaper, } \\
\text { etc. }\end{array}$ & 4.5 & 2.5 & 3.0 & 3.2 & 3.8 & 3.4 & 4.0 & 2.9 & 2.7 & 2.9 & 2.5 & 2.4 & 3.0 & 2.0 & 1.5 \\
\begin{tabular}{l} 
Internet \\
\hline
\end{tabular} & N/A N/A & N/A & N/A N/A & N/A N/A N/A & 0.3 & 1.1 & 2.4 & 3.2 & 2.9 & 3.4 & 5.0 \\
\hline
\end{tabular}

Source: Recording Industry Association of America ("Consumer Profile") 
market power and pose a considerable competitive threat to both chain and independent music stores. ${ }^{2}$ To support this contention, consider the following two sets of data on music sales, from the RIAA and SoundScan.

Data from the RIAA demonstrate that the market share of music sold through "other stores", i.e. stores that sell goods other than pre-recorded music, has increased from $15.6 \%$ of all music sales in 1989 to $52.8 \%$ in 2003 (RIAA, "Consumer Profile"). At the same time, the market share of traditional music stores has declined-from $71.7 \%$ of total sales in 1989 to $33.2 \%$ in 2003 . Music clubs have also seen their market share decline, from around $8 \%$ in the late 1990 s to around $4 \%$ in recent years. Certainly the advent of Internet music sales has made inroads into the market share of non-Internet providers, rising from $0.3 \%$ of total sales in 1997 to around $5 \%$ in 2003, but it appears that traditional record stores have lost significant market share to other stores that sell music.

The general trends apparent in the RIAA figures are supported by market research firm SoundScan (quoted in Almighty Institute of Music Retail), who found that mass-market discounters (such as Wal-Mart, Target, and Best Buy) increased their share of music sales from $26 \%$ in 1996 to $34.9 \%$ in 2003 (an extra \$1.3 billion in sales). During this period sales by chain stores (such as Sam Goody, Virgin, and Tower) declined from $60.3 \%$ to $50.4 \%$ and sales by independent music retailers declined from $13.4 \%$ to $10.8 \%$.

The competitive pressures that traditional record stores are facing are also evidenced when we examine figures on music store closings and bankruptcies over recent years-see Table 2. It is estimated that in 2003 and 2004 around 1,200 stores closed (Cohen). Recent years also saw bankruptcy reorganizations by both Tower Records and Wherehouse Entertainment.

We now turn our attention to the world's largest music retailer, Wal-Mart, and proceed to discuss how traditional music retailers have responded to mass-market discounters in general. I then demonstrate why there appears to be no legal case to be made that Wal-Mart is engaging in predatory pricing. Finally, I examine the impact that Wal-Mart is having in terms of influencing the music that consumers have available to listen to.

\section{Wal-Mart's Market Power}

The largest retailer of music is Wal-Mart-the world's largest company, which as of January 2005 has 3,617 stores across the US and another 1,603 around the world (Wal-Mart). Wal-Mart's annual sales are \$256 billion ("Forbes 2000"). Wal-Mart is also the largest private-sector employer, with around 1.3 million employees worldwide, including over 1 million in the United States (Bhatnagar; Dube and Jacobs; National Public Radio). The company's influence is such that economists refer to the "Wal-Mart effect" - the observation that Wal-Mart, though creating productivity gains, has suppressed inflation (Bianco and Zellner). In 2002, Wal-Mart 
Table 2 Some US Music Store Closings and Bankruptcies in Recent Years

\begin{tabular}{|c|c|}
\hline Chain & Closings \\
\hline CD Warehouse & Closed 23 of its 250 -odd stores in 2002. \\
\hline Harmony House & Liquidated in 2002, closing 19 of 21 stores. \\
\hline HMV & Closed all nine of its US stores between 2002 and 2004 . \\
\hline \multirow{3}{*}{$\begin{array}{l}\text { Musicland (Media } \\
\text { Play, Sam Goody } \\
\text { and SunCoast) }\end{array}$} & $\begin{array}{l}\text { Jan. 2001: Best Buy purchases MusicLand for } \$ 685 \text { million, } \\
\text { obtaining 1,300+ retail stores. }\end{array}$ \\
\hline & $\begin{array}{l}\text { Jan. 2003: Best Buy announces that it will close } 110 \text { Musicland } \\
\text { stores ( } 90 \text { Sam Goody stores and } 20 \text { SunCoast stores). }\end{array}$ \\
\hline & $\begin{array}{l}\text { June 2003: Best Buy sells Musicland, which made an operating loss } \\
\text { of } \$ 72 \text { million on sales of } \$ 1.73 \text { billion in the financial year } \\
\text { ending 2003. No cash was involved in the transaction and the } \\
\text { buyer assumed all liabilities of MusicLand. }\end{array}$ \\
\hline Record Express & Liquidated in 2002, closing 14 of 16 stores. \\
\hline \multirow[t]{2}{*}{ Tower } & $\begin{array}{l}\text { 2002: } \$ 57.2 \text { million net loss, its fourth straight loss. } \\
\text { February 2004: Tower records parent company, MTS Inc, files for } \\
\text { Chapter } 11 \text { bankruptcy. }\end{array}$ \\
\hline & $\begin{array}{l}\text { March 2004: Emerges from bankruptcy with creditors owning } 85 \% \\
\text { of company and looking to sell. }\end{array}$ \\
\hline \multirow[t]{2}{*}{$\begin{array}{l}\text { Wherehouse } \\
\text { Entertainment }\end{array}$} & $\begin{array}{l}\text { Jan. 2003: Files for Chapter } 11 \text { bankruptcy protection, announcing } \\
\text { that it will close } 120 \text { of } 370 \text { stores. }\end{array}$ \\
\hline & $\begin{array}{l}\text { October 2003: Trans World Entertainment acquires Wherehouse } \\
\text { for } \$ 35.6 \text { million in cash and } \$ 5 \text { million in assumed liabilities. }\end{array}$ \\
\hline
\end{tabular}

Sources: "Best Buy to Close 110"; "Best Buy Sells"; "Best Buy Successfully"; Butler; "CD Warehouse"; Christman; Dougherty; Lee and Capell; Lee and Sager; "Reinventing Kmart"; "Trans World"; Wasserman; "Wherehouse Files"

was estimated to have saved US customers $\$ 20$ billion on its own products and $\$ 100$ billion when taking into account the price pressure Wal-Mart places on competitors (Bianco and Zellner).

Wal-Mart is a market leader in a number of industries: In the United States it is the nation's largest retailer of apparel, bedding, groceries, jewelry, and toys (Dube and Jacobs). Of particular interest to us is the fact that Wal-Mart is the largest music retailer, accounting for $20 \%$ of recorded music sales in the US (the company also accounts for $14 \%$ of worldwide music sales and makes one-in-five major-label album sales) (Cohen; Rousseau; "Wal-Mart to Start”).

As is commonplace in many retailing environments, Wal-Mart and other massmarket discounters sell some products as loss-leaders. We will now discuss this practice, and show how traditional music retailers reacted to it. 


\section{Loss Leader Pricing Strategy and Competitors' Response}

The loss-leader pricing strategy (also termed "below-cost" selling) is when a manufacturer, wholesaler, or retailer sells a good or service at or below cost in order to attract (hopefully new) customers and obtain revenue on other (typically more costly) items. Loss-leader products tend to be offered in situations where it is also common for consumers to buy complementary or unrelated merchandise (Walters and Rinne). Loss-leader products offer an incentive for consumers to shop at a given store. Rajiv Lal describes the logic of offering loss-leading products as follows:

Since there are costs to shopping at more than one store, consumers often buy goods that are loss-leaders which are generally priced to adequately compensate for deals offered on loss-leaders. Thus loss-leaders increase store traffic which presumably leads to higher profits though the sale of other products bought by the consumer. (3)

In order to encourage ongoing patronage of a particular store, loss-leaders tend to be products that consumers buy frequently. For loss-leaders to be effective, consumers must be aware of the "regular" price of the product so that they see the loss-leader product as a bargain ("Loss Leader").

Supermarkets commonly use loss-leaders (in the form of specials on soft drinks, sugar, milk, canned goods, etc.) to attract customers to purchase groceries at their store, rather than that of a competitor (Walters and Rinne). The strategy is also commonplace in the gasoline industry where companies such as Marathon often make their profits from the convenience store aspect of their business, rather than from sales of gasoline (Bronson). In the music industry songs sold for 99 cents over iTunes have a limited profit margin and are considered to be almost a loss-leaderused by Apple Computer, Inc. to generate sales for the iPod players (Cuneo et al.). In the brick-and-mortar world of music retailing, Wal-Mart, along with other massmarket discounters such as Best Buy and Target, uses compact discs as a loss-leader, purchasing the CDs from distributors for around \$12 and selling them for less than $\$ 10$ (Cohen).

Owing largely to competition by mass-market discounters, CD prices dropped from around $\$ 14.99$ to as low as $\$ 9.99$ by the mid-1990s (Office of the Attorney General of New York). The result of this was a price war in the market for compact discs. Traditional music retailers were unhappy with the competitive pressures to reduce $\mathrm{CD}$ prices that they were facing from mass-market discounters, including Wal-Mart. In February 1995, Jack Eugster, the CEO of the music retailer Musicland and President of the National Association of Music Retailers (NARM), delivered the keynote address at the NARM convention. In that address Mr Eugster stated that:

For years, wholesalers in many industries have found that minimum advertised price programs [MAP] to qualify co-op dollars have been especially effective in supporting the value of perceptions of their merchandise. Most music companies and movie studios have MAP policies. These programs accomplish their goals best when the MAP is sufficiently above wholesale costs as to not de-value the product 
in the consumers' mind. Also, effective MAP programs consider in-store pricing as well as advertised policies and condition co-op support for the entire ad on MAP compliance. (United States District Court)

The major distributors of music (under pressure from traditional music retailers) introduced increasingly stringent MAP policies — with the effect that there was a ban on informing consumers of discounted prices in print media, electronic media, and in-store displays (with the exception of stickers on the CDs themselves). Stores that violated this policy would have promotional support cut for a period of 60 to 90 days (and violations by an individual store could mean that such support was withdrawn from an entire chain).

According to the Federal Trade Commission, the intent of these efforts was to "illegally modif $[y]$ their existing cooperative advertising programs to induce retailers into charging consumers higher prices for CDs, allowing the distributors to raise their own prices" (Federal Trade Commission). ${ }^{3}$

In 2000 the Federal Trade Commission (FTC) settled charges with the five largest music distributors at the time (Universal Music and Video Distribution, Sony Corp. of America, Time-Warner Inc., EMI Music Distribution, and Bertelsmann Music Group), who agreed to abandon MAPs. The Chairman of the FTC, Robert Pitofsky, observed that MAP may have led consumers to pay as much as $\$ 480$ million during the preceding three-year period (Federal Trade Commission).

The final settlement of the MAP case was for $\$ 67.4$ million, to be distributed to individual states-with consumers being able to seek compensation (Lieberman). Also, as part of the settlement CDs valued at $\$ 75.7$ million were to be distributed to public and non-profit groups (Lieberman).

\section{Legal Implications of Wal-Mart's Pricing Policy}

Efforts in the 1990s by traditional record retailers (and by the major record companies' distribution companies) to curtail the pricing strategies of Wal-Mart and other mass-market discounters using MAPs were unsuccessful. However, the actions of Wal-Mart and others in selling CDs as loss-leaders raise another legal question, namely is Wal-Mart engaging in predatory pricing?

Predatory pricing occurs when a dominant firm sells a product at a loss with the objective of driving competitors from the marketplace. As Thomas J. DiLorenzo explains:

The predatory pricing argument is very simple. The predatory firm first lowers its price until it is below the average cost of its competitors. The competitors must then lower their prices below average cost, thereby losing money on each unit sold. If they fail to cut their prices, they will lose virtually all of their market share; if they do cut their prices, they will eventually go bankrupt. After the competition has been forced out of the market, the predatory firm raises its price, compensating itself for the money it lost while it was engaged in predatory pricing, and earns monopoly profits forever after. 
In the US, claims of predatory pricing fall under Section 2(a) of the Sherman Act. The relevant section of the Sherman Act states that:

Every contract, combination in the form of trust or otherwise, or conspiracy, in restraint of trade or commerce among the several States, or with foreign nations, is declared to be illegal. Every person who shall make any contract or engage in any combination or conspiracy hereby declared to be illegal shall be deemed guilty of a felony, and, on conviction thereof, shall be punished by fine not exceeding $\$ 10,000,000$ if a corporation, or, if any other person, $\$ 350,000$, or by imprisonment not exceeding three years, or by both said punishments, in the discretion of the court. (United States Department of Justice)

It is extremely rare for claims of predatory claims to be tried, and even rarer for such claims to be successful (Matsushita 589). The Supreme Court has upheld in various cases that there are very real competitive benefits to consumers from price competition. Notable cases and key findings include the following:

Matsushita Electric Industrial Co. v. Zenith Radio Corp., 1986

[C] utting prices in order to increase business often is the very essence of competition. Thus, mistaken inferences in cases such as this one are especially costly, because they chill the very conduct the antitrust laws are designed to protect.

Cargill, Inc. v. Monfort of Colorado, Inc., 1986

The kind of competition that [plaintiff] alleges here, competition for increased market share, is not activity forbidden by the antitrust laws. It is simply, as petitioners claim, vigorous competition. To hold that the antitrust laws protect competitors from the loss of profits due to such price competition would, in effect, render illegal any decision by a firm to cut prices in order to increase market share.... [I]t is in the interest of competition to permit dominant firms to engage in vigorous competition, including price competition.

\section{Brooke Group Ltd. v. Brown \& Williamson Tobacco Corp., 1993}

$[\mathrm{T}]$ he costs of an erroneous finding of liability are high.... It would be ironic indeed if the standards for predatory pricing liability were so low that antitrust suits themselves became a tool for keeping prices high. (American Airlines)

A case of predatory pricing against Wal-Mart would likely involve a three-part test: First, is Wal-Mart deliberately reducing its profits (or incurring a loss) for a period of time? Second, are Wal-Mart's actions taken with the "intent" of driving competitors out of business? And third, if competitors are driven out of business, will Wal-Mart be able to recover the losses that it incurred while engaging in predatory pricing?

The answer to the first question is yes (Wal-Mart sells many of its CDs at or below cost and has done so for many years). The answer to the second question is likely to be no as Wal-Mart's actions are not designed to drive competitors out of business. Rather, Wal-Mart's pricing of CDs is intended to attract consumers to their discount stores, so that those consumers will purchase other products. Also, music sales comprise only $2 \%$ of Wal-Mart's overall sales, making it prima facie straightforward for Wal-Mart to argue that they have little (direct) financial incentive to drive other music retailers out of business. Finally, Wal-Mart is 
unlikely to recover losses if it drives competitors out of business. In such a case, if Wal-Mart raised its prices consumers would gravitate to other discount retailers where these $\mathrm{CD}$ are also available or to online sites where they can purchase music. In short, as the writers of a Business Week article titled "Is Wal-Mart too Powerful?" observe, "[g]iants like Wal-Mart have wide latitude to do as they wish to rivals and suppliers so long as they deliver lower prices to consumers" (Bianco and Zellner).

\section{Censorship or Necessary Business Practice?}

While arguments can be made that Wal-Mart's pricing of CDs as loss-leaders benefits consumers, it can also be argued that, in order to appeal to a broad market, WalMart's pricing strategy is essential—as is the company's policy of not stocking records that have parental advisory stickers.

Wal-Mart pursues what is referred to as a cost-leadership business strategy. ${ }^{4}$ This strategy typically involves competing on price, while attempting to control one's costs, in order to maintain higher profit margins than competitors. Wal-Mart is very effective at controlling its costs-through one of the most advanced logistics systems in the world and through placing pressure on suppliers.

In order for a cost-leadership strategy to be successful, a mass-market is usually necessary so that a large sales volume can cover costs. Wal-Mart believes that, in order to cater to this mass-market (or to be "family friendly"), they need to sell products that most consumers want, at a low price (Wal-Mart's tag-line is "Always low prices. Always."). At the same time, Wal-Mart will not risk offending consumers, and therefore chooses not to stock music that has a parental advisory sticker.

To look at the impact of Wal-Mart's decisions we need to consider the types of areas in which they restrict consumers' access to music. In the case of Wal-Mart, issues of censorship relating to pre-recorded music pertain to three areas, namely: lyrical content that is critical of Wal-Mart; cover art; and lyrical content that is such that the music being sold requires parental warning stickers.

\section{Lyrics Directed at Wal-Mart}

In 1996, Wal-Mart refused to stock Sheryl Crow's self-titled album as lyrics to the song "Love is a Good Thing" accused the store of selling guns to minors ("Wal-Mart Blues"). The song, co-written by Crow and Tad Wadhams, contains the lyrics: "Watch out sister/Watch out brother/Watch our children as they kill each other/with a gun they bought at the Wal-Mart discount stores." The album was withdrawn from Wal-Mart shelves after Crow was asked to change the lyrics, and refused. Wal-Mart proposed that the lyrics represented "an unfair, untrue and totally irresponsible comment" (Harper). Wal-Mart also proposed that the lyrics insulted the chain and their employees (Errico). 


\section{Cover Art}

Wal-Mart will not carry CDs with cover art or lyrics that it deems to be overtly sexual or that deal with abortion, homosexuality, or Satanism (Public Broadcasting Service). Consider the following examples of cover art being changed, i.e. alternative versions of cover art being created, because of Wal-Mart's policies: Wal-Mart asked John Mellencamp to brush out images of Jesus Christ and the Devil on the cover of his album Mr. Happy Go Lucky. (The original cover of the album featured a somber circus-like scene of Mellencamp and some children, flanked by images of Jesus Christ and the Devil.) A spokesperson for Mellencamp, Dawn Bridges, was reported as saying at the time that "John didn't design the record cover or conceive it so he doesn't feel terribly personal about it. He said, 'Its OK, fine.' It's not like he was asked to change his music" (Morse). Reportedly the album cover was changed to ensure greater record sales ("Wal-Mart Blues").

Wal-Mart also objected to the back cover of the Nirvana Album In Utero, which portrayed fetuses. The album cover was changed in order to appease Wal-Mart. In Utero was the follow-up to the best-selling Nevermind.

Metal-rock artist Rob Zombie was asked to change the cover of White Zombie's Superswingin' Sexy Sounds and ended up painting bikini straps on a naked woman on a hammock. (The original cover art has the woman posing in a way that covers up areas that could be considered sexually provocative.) ${ }^{5}$ Zombie comments that "WalMart wasn't going to carry the record the way it was. They suggested we put a big black bar across everything. But if we were going to censor it in any way, we wanted it to look good. I didn't do it for Wal-Mart, but for the kids who have no other way of getting the music" (quoted in Morse).

To understand the consequences of Wal-Mart's actions, it is instructive to ask what role cover art plays in the artistic and commercial process. This is a topic on which relatively little has been written in music and media journals; however, some anecdotal advice is provided to artists in various books on how to become successful in the music business. For example, Christopher Knab, author of the book Music is Your Business proposes that " $[y]$ our cover is your calling card to the record industry and to the consumer...how well you design it and the other graphics for your release could well determine your success or failure as a musician."

It is fair to say that album covers are important as they make a statement about the musicians, the music, and even the record label. Consider, for example, the cover art of well-known jazz label Blue Note:

Everything about the Blue Note label in the late 1950s and early 1960s bespoke cool....And topping it all off, Blue Note had those covers. Distinguished by [Alfred] Lions' dramatic, deep shadow musician portraits and designer Reid Miles' imaginative typography, Blue Notes album jackets are beloved not just by jazz fans, but by graphic artists and lovers of great design.... The best Blue Note jackets are perfect echoes of their contents: Bold, direct, dramatic, soulful, strong, just like the hard bop on the thick vinyl inside. They're cool. (Firehammer) 
The impact that an individual album cover can have on a fan is chronicled in Chuck Klosterman's book, Fargo City Rock, wherein he talks about his initial reaction to the cover of the Mötley Crüe album Shout at the Devil:

As cliché as it now seems, I was wholly disturbed by the Shout at the Devil cover. I clearly remember thinking, Who the fuck are these guys? And-more importantly-Are these guys even guys? The blond one looked like a chick and one of the members was named "Nikki". Fortunately, my sister broached this issue seconds after seeing the album cover, and my brother...said "No, they're all guys. They're really twisted, but it's pretty good music." (9)

Artists and labels that create different versions of their cover art for Wal-Mart are inevitably doing so in order to ensure that their music reaches a wider audience. One means by which artists may evaluate their own success is record sales, which is a proxy for the number of people who listen to (and presumably like) their music.

\section{Parental Warning Stickers}

To understand the actions of Wal-Mart and its consequences we need to consider the most significant development in music censorship over the last twenty years, namely the introduction of parental warning labels on music. These labels, which today state "Parental Advisory: Explicit Content", were developed following pressure from the Parents Music Resource Center (PMRC). The PMRC was established in 1985 by the wives of several influential politicians, most notably Tipper Gore, Susan Baker, and Nancy Thurmond ("Parents Music Resource Center"). This group was founded initially "to educate and inform parents of this alarming new trend...towards lyrics that are sexually explicit" (Parents Music Resource Center 1). The PMRC was successful in getting the Senate Commerce, Technology, and Transportation Committee to organize a series of hearings to investigate what the PMRC saw as the pornographic content of rock music, and to discuss a proposed labeling scheme for music. Fearing legislation on this topic, the RIAA (which represented labels accounting for $85 \%$ of music sales) agreed that its members would institute a voluntary labeling scheme. In 1990, this labeling scheme adopted the "Parental Advisor: Explicit Content" stickers that we see on some recordings today. The RIAA ("Parental Advisory") note that these labels are "a notice to consumers that recordings identified by this logo may contain strong language or depictions of violence, sex or substance abuse. Parental discretion is advised." As the following quote from the RIAA demonstrates, the labeling system, although voluntary, appears to have an impact on the content of music recordings:

The RIAA created and now administers the Parental Advisory program. Individual record companies, working with their artists, decide which of their releases should be labeled....In some instances, record companies ask an artist to re-record certain songs or to revise lyrics because a creative and responsible view of the music demands such a revision. Sometimes songs are simply taken off an album. In other 
instances, the artist and the record company agree that there is musical and artistic credibility in the whole of the work even when the lyrics may be too explicit for mainstream distribution. In those instances, the RIAA's Parental Advisory Label is applied prominently to the outside of the permanent packaging. (RIAA, "Parental Advisory")

Needless to say, there is often a marked power imbalance between record companies and artists (with some exceptions, such as when an artist has reached superstar status). This power imbalance means that artists need the financial and promotional support of record companies, which are typically interested in releasing music that has mass appeal. For the RIAA to propose that artists and record company representatives have a balanced discussion about, for example, lyrics, is misleading. The very fact that such conversations take place shows that record companies are (understandably) concerned about the wider appeal (and hence, profitability) of an artist's work. These may oftentimes be concerns that musicians share; however, musicians - unlike their record companies - are more likely to be concerned with the artistic integrity of their work. Hence, when record companies question the lyrical content of artists' work, the artists are put under pressure to consider trade-offs between artistic integrity, the support of their record label, and the perceived impact of their decisions on record sales. As Claude Chastagner writes in his history of the PMRC, “The PMRC's insistence on labeling triggered unofficial though effective forms of censorship, from refusing to sell to refusing to record or produce artists whose lyrics were considered scandalous or licentious, whatever their artistic or social value" (190).

In addition to artists facing pressure from their record companies, the labels and artists face pressure to alter the content of their music (or cover art for their music) from mass-market discounters such as Wal-Mart. In their efforts to maintain what they see as a "family-friendly" environment Wal-Mart have ensured that they stock music that will not offend conservative shoppers. To this end, the company does not sell music in its stores that contains parental guidance stickers. To explain the logic for this decision, Wal-Mart used to include the following statement among the Frequently Asked Questions section on its website:

Wal-Mart will not stock music with parental guidance stickers. While Wal-Mart sets high standards, it would not be possible to eliminate every image, word or topic that an individual might find objectionable. And the goal is not to eliminate the need for parents to review the merchandise their children buy. The policy simply helps eliminate the most objectionable material from Wal-Mart's shelves. (quoted in Public Broadcasting Service)

In short, Wal-Mart claims that they do not stock CDs with parental warning stickers because of customer preferences and out of a desire to help parents. A Public Broadcasting Service documentary about Wal-Mart observes that, "[w]ith its roots in the Southern Christian heartland, Wal-Mart believes that being a 'family' store is the key to their mass appeal." To some extent, this explains Wal-Mart's unwillingness to stock music and other products that may cause offense to shoppers. Interestingly, the 
situation in which Wal-Mart has positioned itself is described by John Ryan in his book The Production of Culture in the Music Industry. Robert Burnett describes Ryan's critique thus:

as long as an organization finds itself in a relatively stable environment...the organization is likely to attempt to maintain the status quo. This is often done by developing products aimed at not offending any group of consumers. Almost invariably, this tactic leads to a high level of product homogeneity which does in fact alienate portions of the consuming market. If the alienated segment becomes large enough, newer firms or firms out of the mainstream are able, through product innovation, to make inroads into the market. (756)

This scenario is evident when we look at Wal-Mart. The company's actions have outraged some individuals, musicians, and record label executives who view Wal-Mart as engaging in, or encouraging, censorship. For example, a group calling itself Rock Out Censorship (ROC) urges consumers to boycott Wal-Mart, stating that "[Wal-Mart's censorship] basically works as a corporate mechanism to keep the music industry in line, creating a situation where the artists face economic ruin if they dare cross Wal-Mart's 'line in the family-values sand'." In a similar vein, Jon Katz, writing in The Netizen in 1996, suggested that readers boycott Wal-Mart because "Wal-Mart shouldn't be allowed to set the country's cultural agenda."

Despite such concerns - and as a consequence of Wal-Mart's policy regarding music with parental advisory labels - the major record companies invariably provide Wal-Mart with sanitized versions of albums. In light of the size of Wal-Mart's customer base, the major record labels feel some pressure to do this. As one EMI Executive Vice President observes, “[y] ou can't have 100\% impact when you are taking an artist to a mainstream audience if you don't have the biggest player, WalMart" (quoted in Bianco and Zellner).

\section{Discussion and Directions for Future Research}

Consumers pay a price of sorts for Wal-Mart's market power and focus on family values as Wal-Mart does not stock music that contains parental warning stickers. In smaller towns, where Wal-Mart may be the only music retailer, consumersparticularly those consumers without Internet access-will have limited ability to buy music with parental warning stickers. Wal-Mart claims that it is supporting parents by not selling music with parental advisory stickers, and that it is meeting the preferences of its consumers. No support is provided for such statements. The notion that Wal-Mart is helping parents by eliminating undesirable merchandise from shelves sounds somewhat patronizing: in essence, Wal-Mart is making choices for parents about what is objectionable and what is not. For Wal-Mart to stock merchandise with parental warning stickers would simply be giving parents (and their children) more choices about what music they can buy. 
Wal-Mart's argument that it does not stock some music owing to consumer preferences is a self-fulfilling prophecy: given that Wal-Mart is the world's largest music retailer, if they choose not to stock individual CDs there is likely to be a lower demand for such CDs. Several research questions come to mind when looking at these dynamics:

1. How do parents (and other shoppers) use parental advisory stickers to make choices about their music purchasing decisions?

2. To what extent are the values of individual shoppers influential in making choices about whether or not to purchase an album with (or without) a parental advisory sticker?

3. When given a choice between buying a "sanitized" CD at Wal-Mart versus going elsewhere-perhaps at greater cost- to buy a CD with a parental warning sticker, what would lead consumers to pursue the latter course of action?

This paper has also raised questions about the pressure that artists and their music companies feel from Wal-Mart to ensure that their lyrical content and cover art do not cause offense. In this regard two research questions come to mind:

1. Do artists and record labels self-censor so that "sanitized" versions of CDs are created for Wal-Mart and other conservative retailers? What impact does this have on record sales?

2. Do artists who choose not to release "sanitized" versions of CDs have more credibility with their fans?

While Wal-Mart uses its market power to benefit consumers-who pay lower prices for music sold as a loss-leader-consumers have less music to select from when shopping at a Wal-Mart store: the typical Wal-Mart store stocks around 5,000 titles, compared to, say, the average Tower Records store, which has around 60,000 titles (Cohen). The practice of offering a limited selection of titles makes commercial sense for Wal-Mart. Since they operate of stores that offer hundreds of product-lines, sales per square foot of retail space will be higher when they choose to stock those products that have the highest customer demand. However, having said this, if Wal-Mart are successful and small independent record stores close in smaller towns, then Wal-Mart is largely dictating what consumer demand will be through the products it makes available. Wal-Mart is likely to have a detrimental impact on the sales of chain and independent record stores, which would often rely upon sales of Top 40 music for a disproportionate amount of their sales revenues.

The impact of mass-market discounters on traditional retailers of music has not been empirically investigated; however, there is some research examining the impact of Wal-Mart on smaller retailers in general.

Lori Franz and Edward Robb examined the impact of Wal-Mart on retailing in rural Missouri counties. One key finding of their study was that "[w]idespread closings of retail stores were reported for most towns after Wal-Mart's entry" (Ganim 
Barnes et al. 22). A 1989 study by Kenneth Stone examined the impact of Wal-Mart on other businesses in Iowa. He found quite different impacts depending upon the products sold by others. When a Wal-Mart opened, businesses that sold the same products tended to experience declining sales. In contrast, businesses that sold products that Wal-Mart did not stock (e.g. specialty retailers) tended to experience higher sales when a Wal-Mart came to town. Stone proposed that this occurred due to more people being attracted to the locations where Wal-Mart operated, thereby benefiting some other retailers.

One direction for future research is to ask what impact the arrival of mass-market discounters has on the sales and survival of traditional music stores. Related to these questions is the need to examine how independent record stores can compete effectively against mass-market discounters. Anecdotal evidence suggests that independent stores approach these competitive pressures by attempting to broaden their product offerings (by, for example, offering videos and clothing), by having an informed staff who can help suggest music that consumers may like, by focusing on genres that their larger competitors do not stock, and by focusing on hard-to-find albums about whose purchase customers are less price-sensitive (Eliscu; Murphy).

In addition to examining the impact of mass-market discounters on traditional (brick-and-mortar) music retailers, it may be instructive for future research to examine what impact Wal-Mart has on the sales of companies that sell compact discs via the Internet, e.g. Amazon.com. Internet retailers typically stock many more titles than the average Wal-Mart store. Under a scenario where Wal-Mart enters a town and becomes the major music retailer and any traditional music stores close, then Internet retailers may pick up some sales of music that Wal-Mart does not stock in its stores. The alternative scenario would see Wal-Mart as bringing more consumers to a given town and thereby providing opportunities for independent music retailers to expand their sales. This could have a detrimental impact on Internet retailers. A study that examines individual music buying habits of consumers before versus after WalMart opens a new store could help shed light on these issues.

Today, Wal-Mart is the world's largest music retailer. As Wal-Mart continues to grow, it is worth asking what impact it will have on consumers' music purchasing behavior. The relatively limited number of titles that Wal-Mart stores stock, combined with the company's focus on "family friendly" merchandising, may not augur well for the success of artists who do not have the support of major record labels or who are unwilling to sacrifice their artistic vision for increased record sales. Also, historically independent music retailers have played a significant role in setting consumer tastes. With sales of such stores declining-partly as a result of the success of mass-market discounters-it is worthwhile to examine the role that independent music retailers play in setting consumer tastes in this changing retail environment. Finally, a study examining the impact of mass-merchandisers on music diversity would be beneficial to see what impact mass-market merchandisers are having on the availability of music. 
The suggestions made above are intended as a stimulus for further research in the realms of music retailing and the role of corporations such as Wal-Mart in music censorship. These areas have traditionally been ignored by popular music researchers.

In light of the significant market power developed by mass-market discounters, traditional chain and independent music stores are facing reduced profits and-in some cases-are closing their doors. Asking how these stores may effectively compete against mass-market discounters is worthwhile as these traditional stores typically offer a wider variety of music for purchase than do mass-market merchandisers. These competitive forces also have implications for the success of musicians-if mass-market retailers have increasing market power, then it becomes that much more difficult for artists on independent labels to reach a wider audience.

Finally, while Wal-Mart's policy of not stocking music with parental warning stickers is commercially justifiable from the point of view of positioning the company as being "family friendly", this practice reduces consumer choice and may well impact the lyrical and packaging (cover art) choices made by musicians and their record labels. To my knowledge, no research has been conducted on corporate censorship and its impact on artists, music labels, and consumers. With more and more music being sold through mass-market discounters, who often seek to promote a "family-friendly" image, it is worthwhile to examine the impact of such censorship - as well as to consider what actions may be undertaken to thwart such attempts at censorship.

\section{Acknowledgments}

This work benefited greatly from the feedback of Gary Burns and Tom McCourt. Also, Fred Naffziger, Professor of Business Law at Indiana University South Bend, provided useful advice regarding some of the legal issues discussed in this paper. All errors or omissions remain the responsibility of the author.

\section{Notes}

[1] Services such as Apple Computer's iTunes, where users can download songs for 99 cents each have been very successful. As of January 2005, 250 million songs had been paid for and downloaded from iTunes, with users downloading over 1.25 million songs every day (Smith). Subscription services have not been as successful as was originally predicted, but this may change with the re-invention of Napster-which offers access to over one million songs for $\$ 14.95$ per month. For a discussion of the development of Internet business models, see Fox ("Technological and Social", "E-commerce").

[2] While the focus of this paper is on mass-market discounters, it is also important to note that other non-traditional retailers are reshaping music retailing. One prominent example of such a retailer is Starbucks which has its own record label and is collaborating with other labels to make music available to the 30 million customers who patronize Starbucks every week. Starbucks is also installing Media Bar kiosks in their stores-to permit customers to make their own compilation albums (Holmes; Schultz). Starbucks' Hear Music collaborated with Concord Records for Ray Charles's album Genius Loves Company ("Starbucks Leads"). The album has gone triple platinum, and more of the CDs were sold in Starbucks stores than in 
any single other retail outlet. Hotels are also increasingly creating compilation albums for guests to purchase (Yancy).

[3] In 2001, the European Commission conducted a similar investigation to determine if the major five record labels had colluded to set prices for CDs in the European Union. Evidence of price-fixing in Germany (by three of the labels) and in Italy (by one of the labels) was discovered. The Commission referred the matter to national authorities in Germany and Italy, to conduct their own investigations ("European Commission Ends").

[4] For a general discussion of the concept of generic strategies, as developed by Michael Porter, see <http://www.quickmba.com/strategy/generic.shtml>.

[5] To view the original cover art, see <http://www.robzombie.com>. To view the Wal-Mart version, see <http://www.Wal-Mart.com/catalog/product.gsp?product_id=834621>.

\section{Works Cited}

Almighty Institute of Music Retail, "Big Box Takeover." 12 Oct. 2004. $<$ http://www.almightyretail.com/newpress.php> Accessed 10 Feb. 2005.

American Airlines. "American Airlines' Response to the Department of Justice's Allegations of Predatory Practices." 1999. $<$ http://www.aadoj.com/other/background.htm> Accessed 10 Feb. 2005.

"Best Buy Successfully Completes Cash Tender Offer for Musicland Stores Corporation." Press Release 23 Jan. 2001. <http://phx.corporate-ir.net/phoenix.zhtml?c=83192\&p=IROLSingleRelease\&t $=$ Regular\&id $=146293 \&>$ Accessed 10 Feb. 2005.

"Best Buy Sells Musicland Subsidiary." Pittsburgh Business Times 16 June 2003. $<$ http://pittsburgh.bizjournals.com/pittsburgh/stories/2003/06/16/daily5.html> Accessed 10 Feb. 2005.

"Best Buy to Close 110 Musicland Stores." Pittsburgh Business Times 9 Jan. 2003. <http://www.bizjournals.com/pittsburgh/stories/2003/01/06/daily48.html> Accessed 10 Feb. 2005.

Bhatnagar, Parija, "Wal-Mart Overhauls Pay, Promotions." CNN/Money 4 June 2004. <http:// money.cnn.com/2004/06/04/news/fortune500/wal_mart/> Accessed 10 Feb. 2005.

Bianco, Anthony, and Wendy Zellner. "Is Wal-Mart too Powerful?" Business Week 6 Oct. 2003. <http://www.businessweek.com/magazine/content/03_40/b3852001_mz001.htm> Accessed 10 Feb. 2005.

Boehlert, Eric. "The Death of Music Retail As We Know It?" Salon 30 May 2000. $<$ http://archive.salon.com/business/feature/2000/05/30/cd_r/> Accessed 10 Feb. 2005. "Payola is Dead! Now What Will We Listen To?" Salon 5 Jan. 2005. <http://www.salon.com/news/feature/2005/01/05/payola/> Accessed 10 Feb. 2005.

"Suit: Clear Channel is an Illegal Monopoly." Salon 8 Aug. 2001. $<$ http://dir.salon.com/ent/clear_channel/2001/08/08/antitrust/index.html> Accessed 10 Feb. 2005.

Bronson, Peter. "Milk or Gas-Which is the Loss Leader?" Cincinnati Inquirer 30 Mar. 2004. <http://www.enquirer.com/editions/2004/03/30/loc_loccollbronson.html> Accessed 10 Feb. 2005.

Burnett, Robert. "The Implications of Ownership Changes on Concentration and Diversity in the Phonogram Industry." Communication Research 19 (1992): 749-69.

Butler, Sarah. "HMV Quits United States on Note of Disappointment." The Times 29 Apr. 2004. <http://business.timesonline.co.uk/article/0,,9074-1091995,00.html> Accessed 10 Feb. 2005.

"CD Warehouse Closing Stores." Dallas Business Journal 6 Nov. 2002. $<$ http://dallas.bizjournals.com/dallas/stories/2002/11/04/daily33.html> Accessed 10 Feb. 2005.

Chastagner, Claude. "The Parents Music Resource Center: From Information to Censorship." Popular Music 18 (1999): 179-92.

Christman, Ed. “Tower Records' Struggles Reflected Industry's Turmoil.” Billboard 28 Dec. 2002: 45. 
Clear Channel. "Entertainment: Music."

$<$ http://www.clearchannel.com/Entertainment/ent_div_music.aspx> Accessed 10 Feb. 2005.

Cohen, Warren. "Wal-Mart Wants \$10 CDs." Rolling Stone 12 Oct. 2004. $<$ http://www.rollingstone.com/news/story/_/id/6558540/> Accessed 10 Feb. 2005.

Crow, Sheryl. "Love is a Good Thing." Sheryl Crow, A\&M, 1996. $<$ http://www.sherylcrow.com/disco.html >

Cuneo, Alice Z., Tobi Elkin, Kim Hank, and T. L. Stanley. "Apple Transcends as Lifestyle Brand." Advertising Age 15 Dec. 2003: S2.

DiLorenzo, Thomas J. "The Myth of Predatory Pricing." Cato Policy Analysis No. 16928 Feb. 1992. $<$ http://www.cato.org/pubs/pas/pa-169.html> Accessed 10 Feb. 2005.

Dougherty, Conor. "Tower Records' Parent on Track to File for Chapter 11." San Diego UnionTribune 6 Feb. 2004.

<http://www.signonsandiego.com/news/business/20040206-9999_1b6tower.html> Accessed 10 Feb. 2005.

Dube, Arindrajit, and Ken Jacobs. "Hidden Cost of Wal-Mart Jobs: Use of Safety Net Programs by Wal-Mart Workers in California.” U.C. Berkeley Labor Center Study 2 Aug. 2004. $<$ http://www.dsausa.org/lowwage/Wal-Mart/2004/Wal-Mart\%20study.html> Accessed 10 Feb. 2005.

du Gay, Paul, and Keith Negus. "The Changing Sites of Sound: Music Retailing and the Composition of Consumers." Media, Culture and Society 16 (1993): 395-413.

Eliscu, Jenny. "Record Stores Struggle to Survive." Rolling Stone 4 Sept. 2003: 54.

Errico, Marcus. "Wal-Mart Bans Sheryl Crow's Next Album.” EOnline 10 Sept. 1996. $<$ http://www.eonline.com/News/Items/0,1,159,00.html> Accessed 10 Feb. 2005.

"European Commission Ends CD Price-Fixing Investigation." Digital Media Wire 17 Aug. 2001. $<$ http://www.digitalmediawire.com/archives_081701.html> Accessed 10 Feb. 2005.

Federal Trade Commission. "Record Companies Settle FTC Charges of Restraining Competition in CD Music Market.” Press Release. 10 May 2000.

<http://www.ftc.gov/opa/2000/05/cdpres.htm> Accessed 10 Feb. 2005.

Firehammer, John. "Book Review: Blue Note 2: The Album Cover Art." All About Jazz 8 Mar. 2004. $<$ http://www.allaboutjazz.com/php/article.php?id=1302> Accessed 10 Feb. 2005.

“The Forbes 2000, The World's Leading Companies." Forbes 25 March 2004. <http://www.forbes.com/lists/2004/03/24/04f2000land.html> Accessed 10 Feb. 2005.

Fox, Mark A. "E-commerce Business Models for the Music Industry." Popular Music and Society 27 (2004): 201-20.

"Technological and Social Drivers of Change in the Online Music Industry." First Monday 7.2 (2002) < http://www.firstmonday.org/issues/issue7_2/fox/index.html> Accessed 10 Feb. 2005.

Fox, Pimm. "The Day the Music Stores Died." ComputerWorld 24 May 2004. $<$ http://www.computerworld.com/managementtopics/ebusiness/story/0,10801,93316,00.html> Accessed 10 Feb. 2005.

Franz, Lori, and Edward Robb. "Effect of Wal-Mart Stores on Economic Environment of Rural Communities." Unpublished Study, University of Missouri, 1989.

Ganim Barnes, Nora, Allison Connell, Lisa Hermenegildo, and Lucinda Mattson. "Regional Differences in the Economic Impact of Wal-Mart-Retail Industry." Business Horizons 39.4 (1996): 21-25.

Harper, Liz. "Wal-Mart: Impact of a Retail Giant." Public Broadcasting Service 20 Aug. 2004. <http://www.pbs.org/newshour/bb/business/wal-mart/impact.html> Accessed $10 \mathrm{Feb} .2005$.

Holmes, Stanley. "First the Music, Then the Coffee." Business Week 22 Nov. 2004. $<$ http://www.businessweek.com/magazine/content/04_47/b3909094_mz017.htm> Accessed 10 Feb. 2005.

Hopkins, Nic. "Spitzer Rounds on Music Giants." The Times 23 Oct. 2004: 62.

Katz, Jon. "The Web vs. Wal-Mart." The Netizen 14 Nov. 1996. <http://webmonkey.wired.com/netizen/96/46/katz4a.html> Accessed 10 Feb. 2005.

Klosterman, Chuck. Fargo Rock City. New York: Scribner, 2002.

Knab, Christopher. "Your CD Cover Is Your Most Important Advertisement." May 2002. 10 Feb. 2005 <http://www.musicbizacademy.com/knab/articles/cdcover.htm> 
Lal, Rajiv. "Consumer Expectations and Loss-Leader Pricing in Retail Stores." Research Paper 1142, Graduate School of Business, Stanford University, 1991.

Lee, Louise, and Kerry Capell. “Taps for Music Retailers?” Business Week 23 June 2003. $<$ http://www.businessweek.com/magazine/content/03_25/b3838044.htm> Accessed 10 Feb. 2005.

Lee, Louise, and Ira Sager. “Tower: Not Such a Golden Oldie.” Business Week 2 June 2003. <http://www.businessweek.com/magazine/content/03_22/c3835012_mz003.htm\#B3835014> Accessed 10 Feb. 2005.

Lieberman, David. "States Settle CD Price-Fixing Case." USA Today 30 Sept. 2002. $<$ http://www.usatoday.com/life/music/news/2002-09-30-cd-settlement_x.htm> Accessed 10 Feb. 2005.

"Loss leader." Wikipedia 10 Feb. 2005. <http://en.wikipedia.org/wiki/Loss_leader> Accessed 10 Feb. 2005.

Matsushita Elec. Indus. Co. v. Zenith Radio Corp. 475 U.S. 574. 26 March 1986.

Morse, Steve. "Up Against the Wal-Mart: Rockers and Rappers Claim Censorship." Boston Globe 6 Dec. 1996: C13.

Mötley Crüe. "Shout at the Devil." Mötley Crüe. Motley/Beyond, 1983.

Murphy, H. Lee. "Niche Shops Fight the Blues.” Crain's Chicago Business 8 July 2002: SB4.

National Public Radio. "Wal-Mart's Social and Economic Impact." June 2003. <http://www.npr.org/news/specials/Wal-Mart/> Accessed 10 Feb. 2005.

Office of the Attorney General of New York. "Spitzer Announces Price-Fixing Lawsuit against Major Record Companies and Retailers." Press Release 8 August 2000.

$<$ http://www.oag.state.ny.us/press/2000/aug/aug08a_00_attach.pdf> Accessed 10 Feb. 2005.

Parents Music Resource Center. Statement of Susan Baker and Tipper Gore [of the] PMRC before the Senate Commerce Committee, 1985.

"Parents Music Resource Center." Wikipedia <http://en.wikipedia.org/wiki/PMRC> Accessed 10 Feb. 2005.

"Pearl Jam's Testimony before Congress Regarding Ticketmaster." Testimony before the Information, Justice, Transportation and Agriculture Subcommittee of the House Committee on Government Operations. 30 June 2003. $<$ http://www.fivehorizons.com/archive/articles/testimon.shtml> Accessed 10 Feb. 2005.

Public Broadcasting Service. "Store Wars: When Wal-Mart Comes to Town." <http://www.pbs.org/itvs/storewars/stores3_2.html> Accessed 10 Feb. 2005.

Recording Industry Association of America. "Consumer Profile." 1998, 2003. $<$ http://www.riaa.com/news/marketingdata/purchasing.asp> Accessed 10 Feb. 2005. "Parental Advisory." 2003. <http://www.riaa.com/issues/parents/advisory.asp> Accessed 10 Feb. 2005.

“Reinventing Kmart.” Fool.com 16 June 2003. <http://www.fool.com/news/take/2003/take030616.htm> Accessed 10 Feb. 2005.

Rock Out Censorship. "ROC Calls for a National Boycott of the 'Evil Wal-Mart Empire'." $<$ http://www.akphantom.com/ROC1.html> Accessed 10 Feb. 2005.

Rousseau, Caryn. "Wal-Mart to Launch Online Music Service." USA Today 14 Nov. 2003. <http://www.usatoday.com/tech/webguide/music/2003-11-14-walmart-music_x.htm> Accessed 10 Feb. 2005.

Ryan, John. The Production of Culture in the Music Industry. New York: University Press of America, 1985.

Schultz, Howard. "Something's Brewing." Billboard 23 Oct. 2004: 10.

Smith, Tony. "Apple iTunes Sales Tally Hits 250m." The Register 24 Jan. 2005. <http://www.theregister.co.uk/2005/01/24/apple_itunes_tally> Accessed 10 Feb. 2005.

"Sony and BMG Merger Backed by EU." BBC News 19 July 2004. $<$ http://news.bbc.co.uk/2/hi/business/3908405.stm> Accessed 10 Feb. 2005.

"Starbucks Leads Unprecedented Change in Music Industry, and Helps Take Ray Charles to the Top." Music Industry News Network 13 Sept. 2004. <http://www.mi2n.com/press.php3?press_nb=71196> Accessed 10 Feb. 2005. 
Stone, Kenneth. "The Impact of Wal-Mart Stores on Other Businesses in Iowa." Unpublished study, Iowa State University, Oct. 1992. The findings of the study are summarized at $<$ http://www.emich.edu/public/geo/557book/c312.stone.html>

"Trans World Entertainment Obtains Court Approval for the Asset Acquisition of Wherehouse Entertainment, Inc. Trans World Entertainment Corp.” News Release 30 Sept. 2003. <http://www.twec.com/corpsite/corporate/press.cfm> Accessed 10 Feb. 2005.

United States Department of Justice. Antitrust Division Manual. <http://www.usdoj.gov/atr/foia/divisionmanual/ch2.htm\#a1> Accessed 10 Feb. 2005.

United States District Court, District of Maine, Re: Compact Disc Minimum Price Antitrust Litigation. <http://www.musiccdsettlement.com/english/Complaint.htm>

Wal-Mart. "Investor Relations: Wal-Mart Corporate Profile." $<$ http://www.walmart.com/cservice/aw_index.gsp> Accessed 10 Feb. 2005.

"Wal-Mart Blues." Sonoma County Independent 9-15 Jan. 1997. $<$ http://www.metroactive.com/papers/sonoma/01.09.97/Wal-Mart-music-9702.html> Accessed 10 Feb. 2005.

"Wal-Mart to Start Music Download Service this Year, People Say." Bloomberg 6 Nov. 2003. $<$ http://quote.bloomberg.com/apps/news?pid=10000103\&sid=arsZlqzCq9ic $>$ Accessed 10 Feb. 2005.

Walters, Rockney G., and Heikki J. Rinne. "An Empirical Investigation into the Impact of Price Promotions on Retail Store Performance." Journal of Retailing 62 (1986): 237-66.

Wasserman, Jim. "Tower Records Emerges from Bankruptcy in Delaware Court." 15 SignOnSanDiego March 2004.

<http://www.signonsandiego.com/news/business/20040315-1358-ca-towerrecords.html> Accessed 10 Feb. 2005.

"Wherehouse Files for Bankruptcy." The Detroit News 22 Jan. 2003. <http://www.detnews.com/2003/business/0301/22/c04-65904.htm> Accessed 10 Feb. 2005.

Yancy, Kitty Bean. "Hotels in Tune with Guests, and Vice Versa." USA Today 18 Feb. 2005: D1.

Yang, Ginny. "Changing the Channel." Spin 29 Jan. 2004.

$<$ http://www.spin.com/features/exclusives/2004/01/changing_channel> Accessed 10 Feb. 2005. 